\title{
RECENT ADVANCES ON GEOMORPHOLOGY OF THE GORCE MOUNTAINS, THE OUTER WESTERN CARPATHIANS - STATE-OF-THE-ART AND FUTURE PERSPECTIVES
}

\author{
Paweł Kroh ${ }^{1}$ (D) Łukasz Pawlik ${ }^{2}$ (D) \\ ${ }^{1}$ Institute of Geography \\ Pedagogical University of Krakow \\ Podchorążych 2, 30-084 Krakow: Poland \\ e-mail: pawel.kroh@up.krakow.pl (corresponding author) \\ ${ }^{2}$ Faculty of Natural Sciences, Institute of Earth Sciences \\ University of Silesia \\ Będzińska 60, 42-200 Sosnowiec: Poland \\ e-mail: lukasz.pawlik@us.edu.pl
}

\begin{abstract}
The increase of geomorphological research during the last decades in the Gorce Mts. caused the need for state-of-art review papers. The Gorce Mountains were formed as an isolated massif with Mt Turbacz (1310 $\mathrm{m}$ a.s.l.) as the highest summit. River channels are remodeled by sudden and high-level floods with the critical impact of log jams. The main processes influencing hillslope relief were landsliding, run-off, and tree uprooting. The review suggests the following issues await for studies: a long-term landscape evolution, monitoring of morphogenetic processes, and origin of landslides with their contribution to denudation rates. Also, current biomorphodynamics (uprooting process) has not been sufficiently studied.
\end{abstract}

\section{Key words}

Geomorphology • relief - landslides - hillslope processes - fluvial processes - human impact • biomorphodynamics

\section{Introduction}

The Gorce Mts. massif occupies a special place on the geomorphological map of Poland. As a vast and isolated complex of hills featuring a horn-like structure, it is an area of exceptional geomorphological conditions, a specific radial river network, and a mountain climate. Moreover, geological evolution and geological structure of this part of the Western Carpathians played a vital role in the present-day relief of the Gorce Mts. (e.g., Burtan et al., 1978; Cieszkowski et al., 2015; Forma \& Zuchiewicz, 2002), including primarily deep overthrust (slice-nappe) structure, the resistance of rocks building 
various parts of the Carpathian flysch, finally neotectonic movements responsible for the leading features of the contemporary Gorce Mts. relief.

The main elements of Gorce Mts. natural environment were described many times. Jarosz's (1935) paper was one of the first scientific manuscripts characterizing forests and forest management in this area. However, in Earth sciences, a long history of geological and geomorphological studies resulted in many research papers. Still, the lack of a synthesis of the entire massif motivated us to take steps in this direction. The interest in the Gorce Mts. relief and processes shaping it started already at the beginning of the 20th century. However, numerous results of studies carried out in the massif are now dispersed in various publications. This paper aims to review the hitherto literature for the first time and present synthetically the data describing the relief of the entire Gorce Mts. mesoregion. The Gorce Mts. relief and geomorphological processes responsible for the development of massif surface forms on various space and time scales were described in the study. Also, recent authors' studies on landslide processes, biological weathering, and biotransport were considered. The prospects of further geomorphological investigations in the Gorce Mts. range were discussed, emphasizing the Gorce National Park.

\section{Location of the study area and its main physical and geographical features \\ Location and geological structure}

The Gorce Mts. are a part of a vast system of the Carpathians range extending from the southern-western border of Romania up to the northern-eastern frontiers of Austria (from the Iron Gates to the Vienna Woods along nearly 1300 km; Zuchiewicz, 2010). This massif is a mesoregion (513.52) expanding latitudinally, situated in the central part of the Outer Western Carpathians sub-province, and is a part of the Western
Beskidy macroregion (513.4-5). On the north, it borders with the Beskid Wyspowy Mts. On the south with the Orawa-Nowy Targ Basin (Fig. 1). In the east, it neighbors with the Beskid Saqecki Mts. (also translated as 'Sacz Beskid'), while in the west with the Orawa-Jordanów Foothills (Balon \& Jodłowski, 2014; Solon et al., 2018). In Poland's geomorphological division, the Gorce Mts. belong to the Beskid Sadecki Mts. region (Klimaszewski \& Starkel, 1972; Gilewska, 1986). The Gorce National Park was established in the central part of this mesoregion in 1981 (Fig. 2).

The Gorce Mts. relief reflects a slice-nappe structure and main tectonic elements of the Western Carpathians geological structure, in which individual segments (nappes, slices, folds, faults) feature different age, lithology, and course. In the case of rocks building separate bedrock parts, they differ in the resistance to external damaging factors (weathering and erosion) (Kania \& Szczęch, 2020). Such a Western Carpathians structure comprises three vast nappes (Magura, Silesian, and Skole) (Ksiq̨zkiewicz, 1971; Oszczypko, 1995; Żytko et al., 1989). The Gorce Mts. massif originated within the biggest of them, the Magura nappe (Cieszkowski et al., 1985, 2015; Szczęch et al., 2016). The Magura nappe represents a late Oligocene - early Miocene accretion prism consisting of the following slices: Krynica, Bystrzyca, Racza, and Siary (Zuchiewicz, 2010). Its thickness is estimated at 2.5-3.5 km (Zuchiewicz, 2010), and it is built of alternating sandstones, shales, and marls of the flysch series ranging in age from the Cretaceous to the Oligocene (Książkiewicz, 1971, Oszczypko, 1995; Forma \& Zuchiewicz, 2001; 2002; Oszczypko \& Oszczypko-Clowes, 2011; Olszak, 2011).

In the south, the Gorce Mts. are separated from the Orawa-Nowy Targ Basin by a normal fault featuring a few hundred meters throw (Zuchiewicz, 2001; Pomianowski, 2003). The area of Gorce Mts. is still subject to neotectonic movements (Olszak, 2009; Buczek \& Górnik, 2019). In the east, the Lubań range is separated from the Beskid Sadecki Mts. by the Dunajec fault. In the Quaternary, 


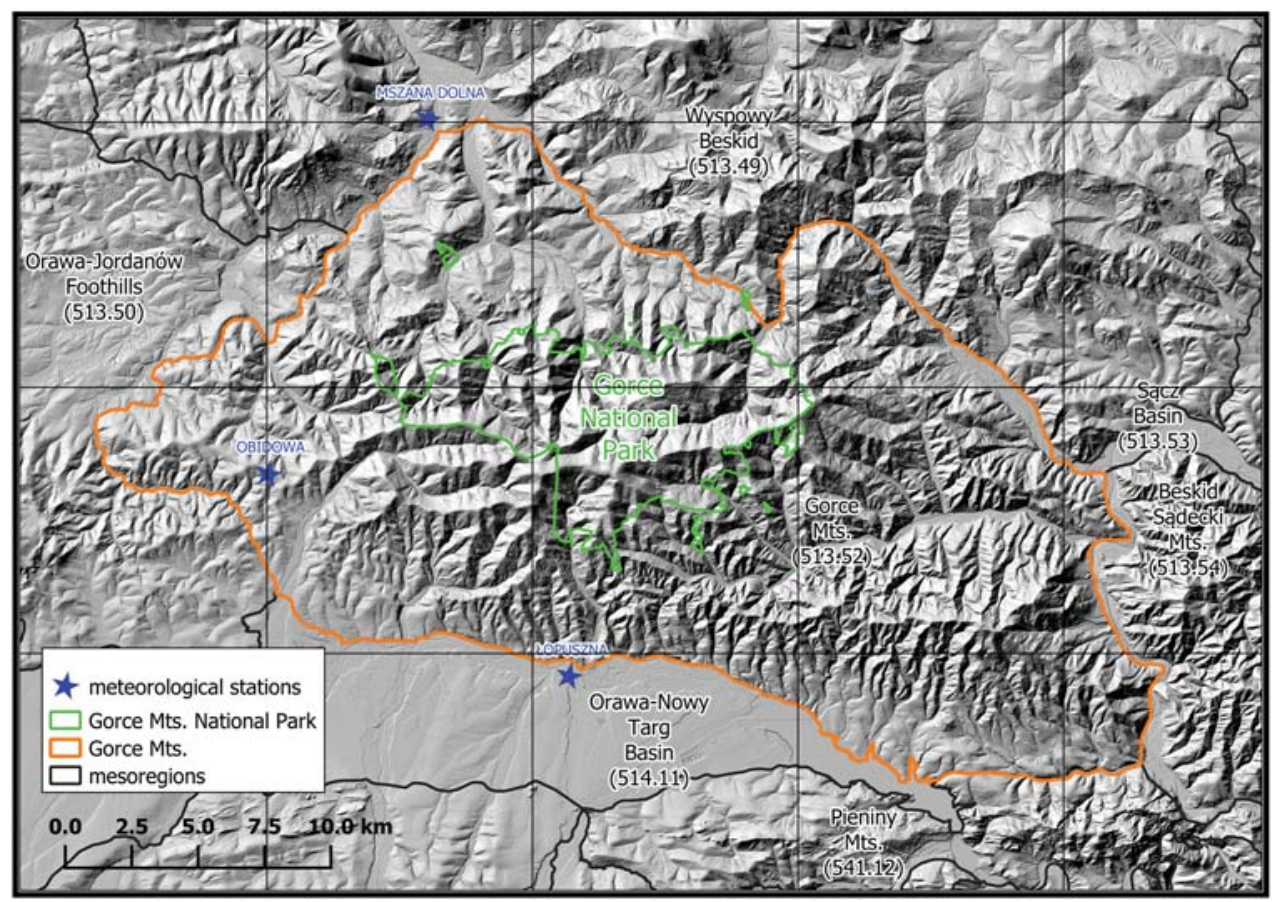

Figure 1. The Gorce Mountains in a regional context and the Gorce National Park (GPN) within the Gorce mesoregion

Source: Authors' own work based on Solon et al. (2018).

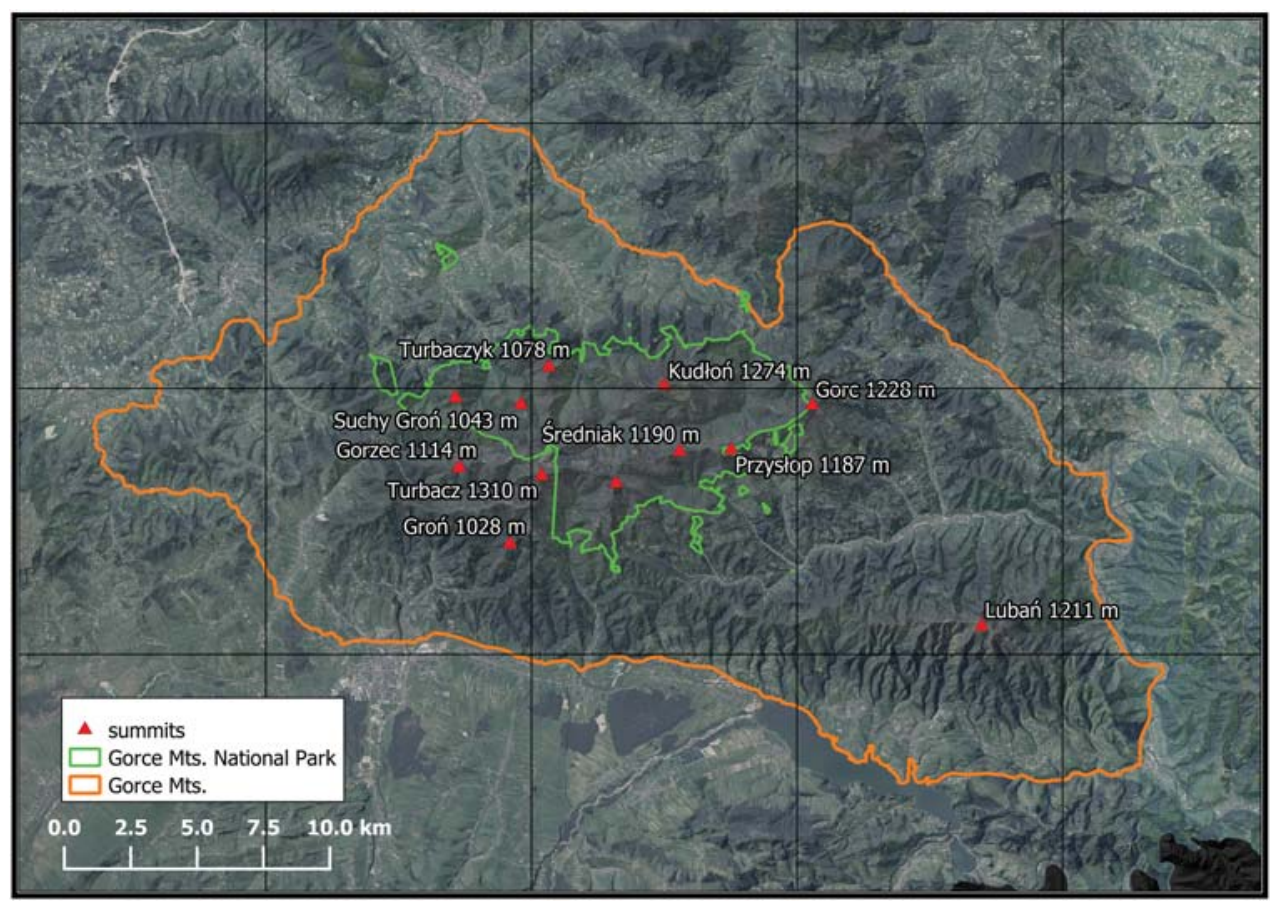

Figure 2. Orthophotomap based on the Google Maps data set showing land cover of the Gorce Mts. and the Gorce National Park 
the Gorce Mts., like the whole Carpathians, were subject to neotectonic movements in three main phases: 800-472, 130-90, and $15-0$ thousand years ago (Zuchiewicz, 1998), which combined with glacial-interglacial cycles and diversified deposition of the slope material resulted in the development of a sequence of terraces, which age can reach even 190,000 years BP (Zuchiewicz, 1992; Olszak, 2011).

\section{Climate, surface waters, and plant cover}

So far, the Gorce Mts. climate was precisely identified by Obrębska-Starklowa (1968, 1969a, 1969b) and supplemented by other researchers (Miczyński, 2015). Within the present study, three stations were chosen for analysis. The station in Obidowa (805 m a.s.l.) is at the highest elevation on the ridge (data for 1992-2019). The Łopuszna station (570 m a.s.l., data for 1988-2017) is at the boundary between the Gorce Mts. and the Orawa-Nowy Targ Basin, at the southern foothill of the Gorce. While the station in Mszana Dolna (440 m a.s.l., data for 1961-2019) is situated already in the Beskid Wyspowy Mts. in the area as regarded the northern foothill of the Gorce massif. There are two more meteorological stations in the study area that could not have been used.
The first one is placed on the Mt Suhora Astronomical Observatory. It is an automatic meteorological station installed on the building's roof, thus failing to meet the standard measuring station's international requirements. The second station is near the Turbacz summit area, but this data is still not available in open-source databases.

The average annual temperature for the Mszana Dolna station is $7.4^{\circ} \mathrm{C}$, and it is higher by $1.3^{\circ} \mathrm{C}\left(6.1^{\circ} \mathrm{C}\right)$ and by $1.5^{\circ} \mathrm{C}\left(5.9^{\circ} \mathrm{C}\right)$ from the average temperature for the Łopuszna and Obidowa stations, respectively (Tab.). The values of absolute maximal temperature differ by nearly $3^{\circ} \mathrm{C}$ between the highest and the lowest station. A still more significant difference exists for the absolute minimum temperature, but the Obidowa station, despite situated higher, features a higher minimum temperature $-28^{\circ} \mathrm{C}$. However, this is a station with southern exposure.

The annual precipitation is $813 \mathrm{~mm}$ in the south part of the mountains (Łopuszna station), $873 \mathrm{~mm}$ on the north slopes (Mszana Dolna), and the highest on the west part (Obidowa - $881 \mathrm{~mm}$ ). An average annual number of days with snow cover changes proportionally to the elevation, from 6.9 days in Mszana Dolna to 8.7 days in Obidowa. The highest annual precipitation sums were recorded for the Łopuszna and Obidowa stations in the same years: 2001, 2007,

Table. Major climate parameters for the selected meteorological stations in the Gorce Mts.

\begin{tabular}{|l|c|c|c|}
\hline \multicolumn{1}{|c|}{ Paramater } & Mszana Dolna & Łopuszna & Obidowa \\
\hline Elevation [m a.s.I.] & 440 & 570 & 805 \\
Absolute maximal temperature $\left[{ }^{\circ} \mathrm{C}\right]$ & 36.0 & 34.8 & 33.2 \\
Absolute minimal temperature $\left[{ }^{\circ} \mathrm{C}\right]$ & -34.0 & -35.0 & -28.0 \\
Mean annual temperature $\left[{ }^{\circ} \mathrm{C}\right]$ & 7.4 & 6.1 & 5.9 \\
Mean annual precipitation $[\mathrm{mm}]$ & 873 & 813 & 881 \\
Mean sum of precipitation in January & 46 & 40 & 143 \\
Mean sum of precipitation in July & 120 & 135 & $100.7 \mathrm{~mm}$ \\
Highest recorded daily precipitation $[\mathrm{mm}]$ & $139.0 \mathrm{~mm}$ & $104.6 \mathrm{~mm}$ & $(15.05 .2014$ r. $)$ \\
Mean annual number of days with snow cover & 81 & $(08.07 .1997 \mathrm{r})$. & 102 \\
\hline
\end{tabular}

Source: https://danepubliczne.imgw.pl/ 
and 2010 (Fig. 3). They exceeded $1000 \mathrm{~mm}$. In Mszana Dolna, high precipitation, close to $1200 \mathrm{~mm}$ per year, was recorded in 1996 and 1970 (missing data for the 1980s and 1990s). In all cases, the highest monthly precipitation was recorded in June and July, while the maximal temperature in July and September (Fig. 4).

The Gorce massif is drained by tributaries of rivers with regional reach: Raba and Dunajec. The massif features a dense river network, which originates within the highest Gorce mountain tops, slopes, and plateaus. It then develops radially, following concentrically spreading main ridges and valleys (Fig. 5). The density of the Gorce Mts. river network reaches nearly $5.5 \mathrm{~km} \cdot \mathrm{km}^{-2}$ (Fig. 6). The majority of rivers feature very deeply cut valleys. The valleys of Jaszcze and Jamne rivers were best studied up to now (Obrębska-Starklowa, 1969b; Bucała, 2009, 2010, 2012; Bucała et al., 2016).

The parts of Gorce Mts. with the highest elevations and the steepest slopes are most often afforested with stands of prevailing fir, spruce, and beech. However, between 1992 and 1997, the decline of natural regeneration of Norway spruce was observed (Chwistek, 2001), and since 1997 farther significant loss (6.5\%) of Norway spruce stands was detected (Wezyk et al., 2018). A natural upper forest boundary is missing, and the existing one results from human activity, including forest cutting in the area of passes and plateaus for pasturing purposes (Bucała et al., 2015; Bucała-Hrabia, 2017, 2018). The lower forest boundary is situated along the farming-forest border and can reach even $1000 \mathrm{~m}$ a.s.l.

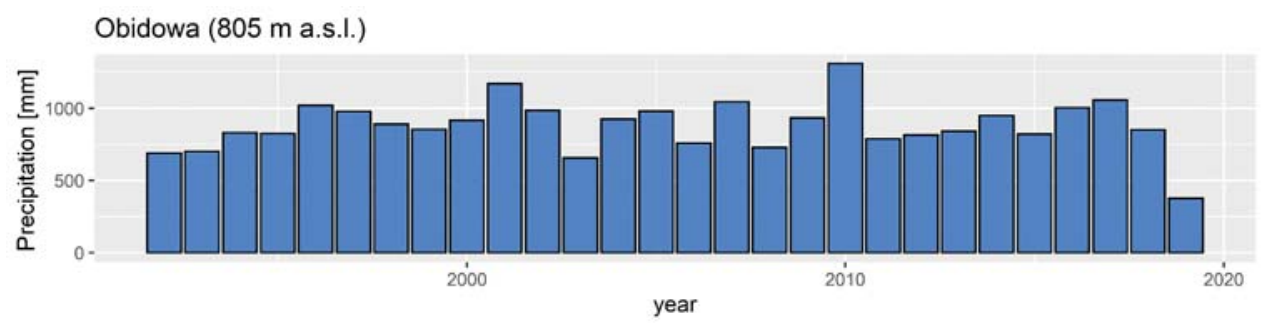

Łopuszna (570 m a.s.I.)
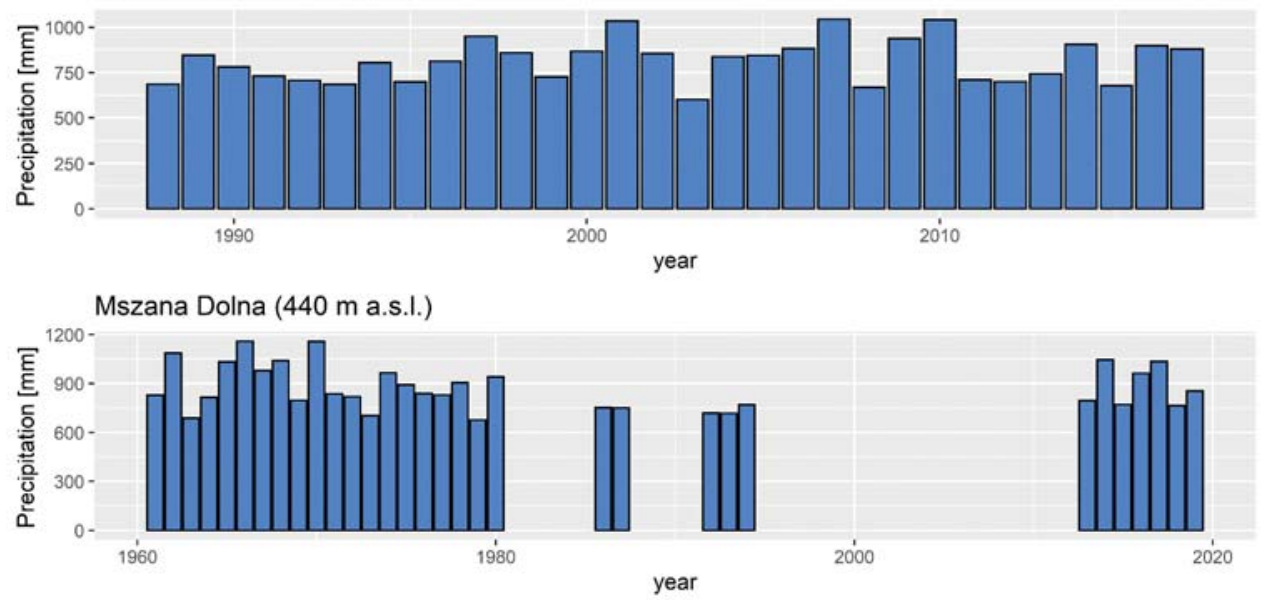

Figure 3. Annual precipitation calculated for selected meteorological stations

Source: Authors' own work based on public data available from the Institute of Meteorology and Water Management (https://danepubliczne.imgw.pl/). 


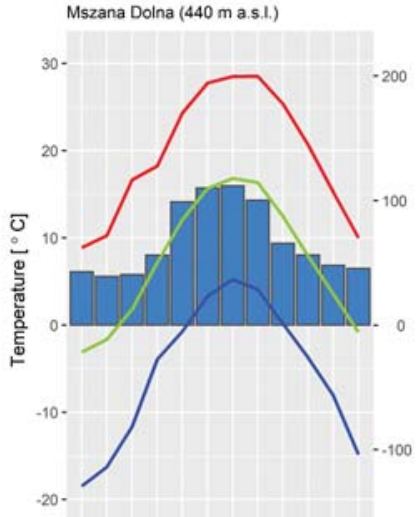

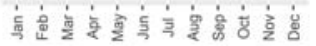

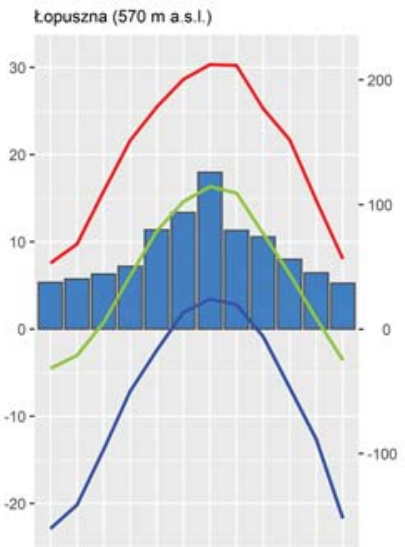

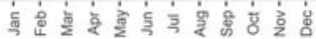

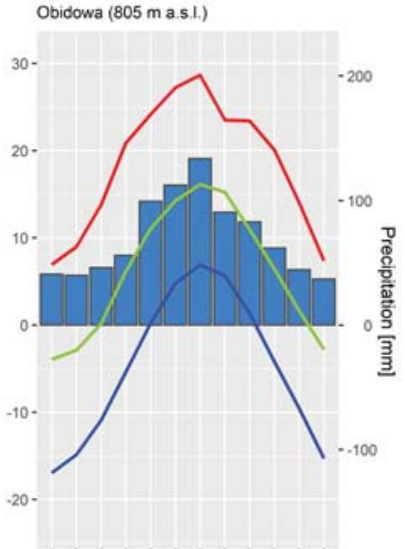

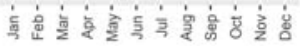

Figure 4. Climate diagrams made for selected stations from the Gorce Mts. area. Red line - average absolute maximum monthly temperature, green line - average monthly temperature, blue line - average absolute minimum temperature.

Source: Authors' own work base on public data available from the Institute of Meteorology and Water Management (https://danepubliczne.imgw.pl/).

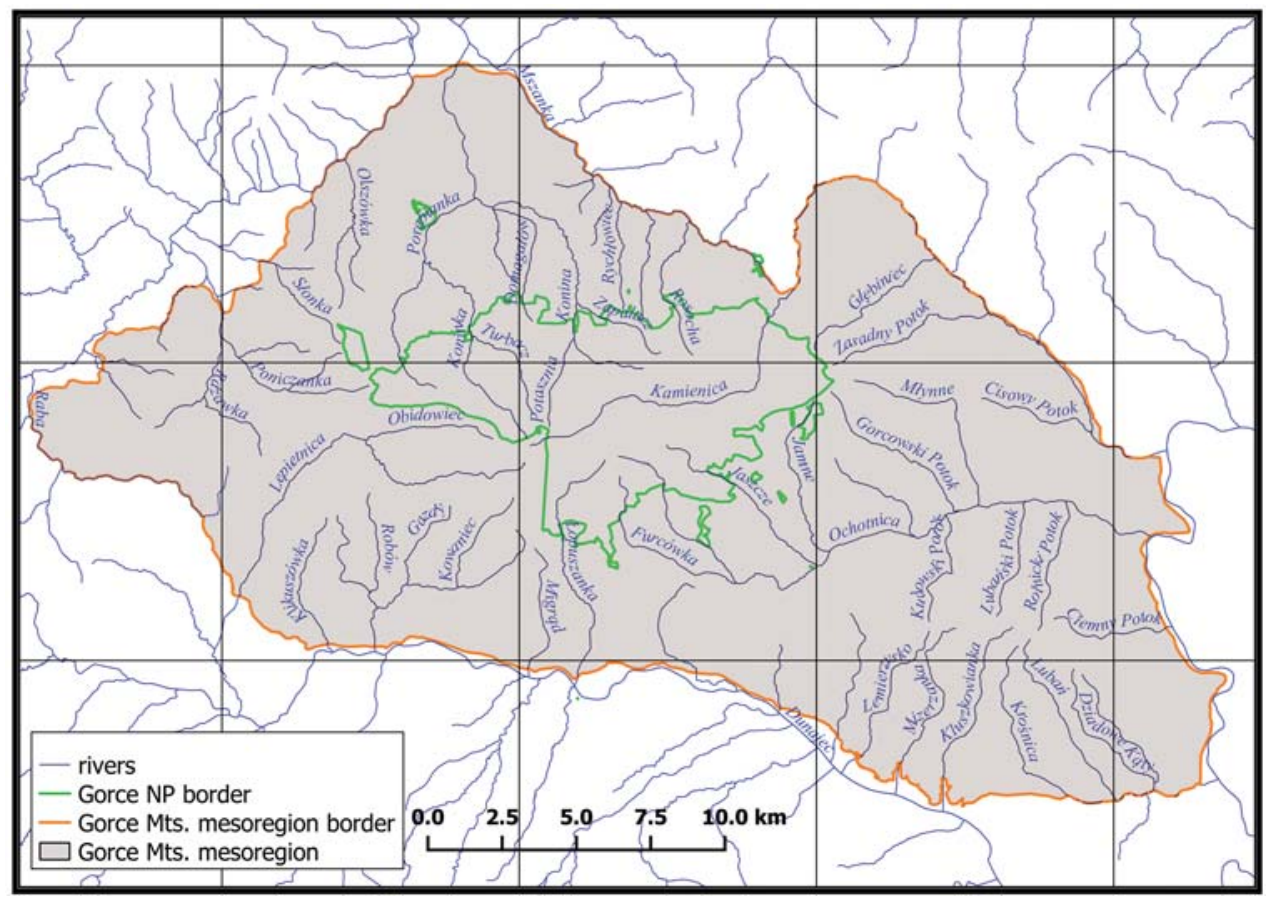

Figure 5. The Gorce Mts. and the Gorce National Park (GPN) river network based on the hydrographic map of Poland in 1:50,000 scale

Source: Authors' own work based on public data (https://dane.gov.pl/dataset/869,komputerowa-mapapodziau-hydrograficznego-polski). 


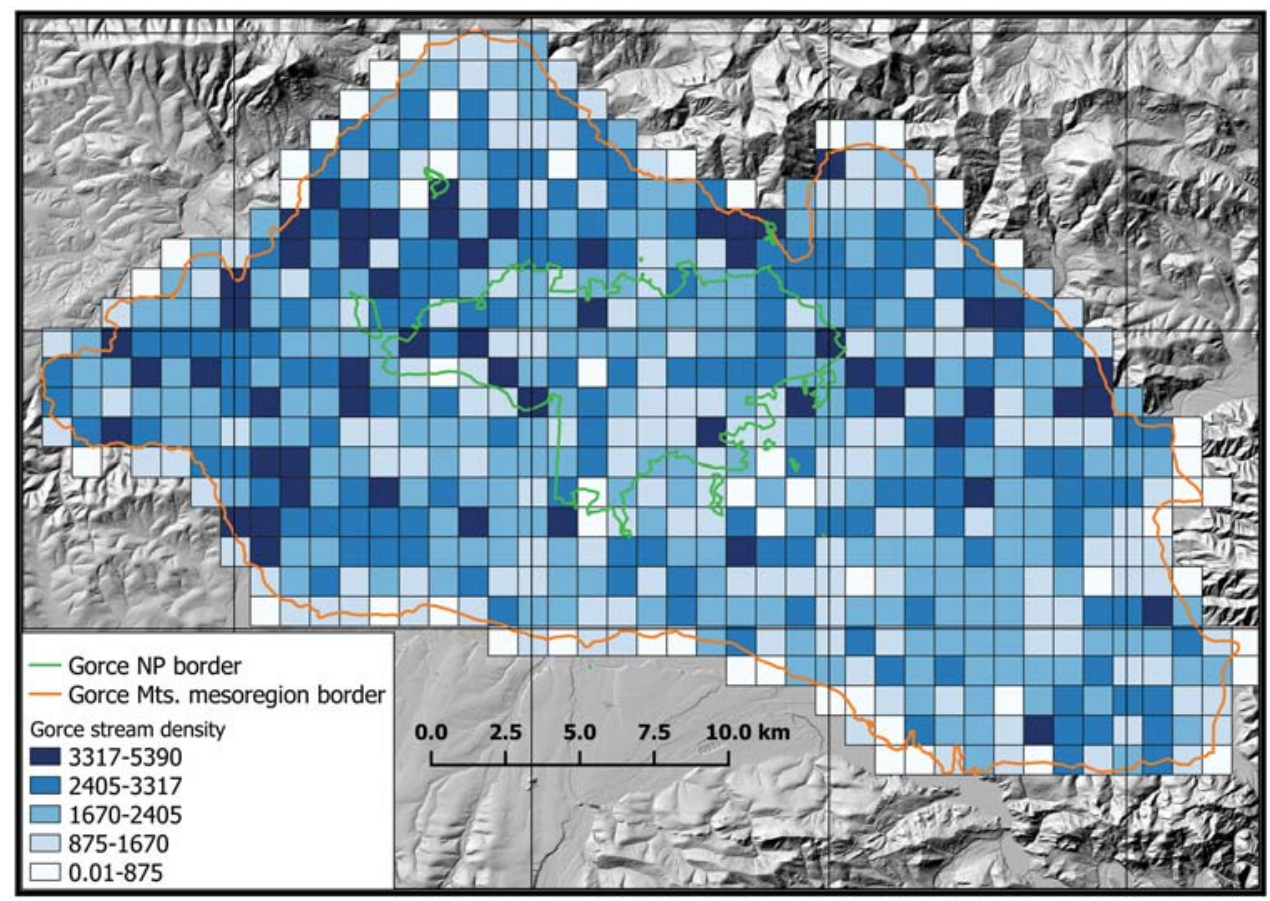

Figure 6. The Gorce Mts. river network density in $\mathrm{m} \cdot \mathrm{km}^{-2}$

Source: Authors' own work based on the Geodatabase of Topographic Objects (http://www.gugik.gov.pl/ pzgik/zamow-dane/baza-danych-obiektow-topograficznych-bdot-10k).

\section{General Overview of the Gorce Mountains relief}

The Turbacz peak with an elevation of $1310 \mathrm{~m}$ a.s.l is the highest point of Gorce Mts. The Gorce Mts. foothills on the southern side (Orawa-Nowy Targ Basin) are at an elevation of approx. $580 \mathrm{~m}$ a.s.l., and on the northern side, in the area of Mszana Dolna, approx. $450 \mathrm{~m}$ a.s.l. So the massif elevation differences exceed 850 meters, and the southern slopes feature much bigger differences in elevation (Fig. 7). The distance between Turbacz and the northern outskirts of the region is approx. $16 \mathrm{~km}$, which gives an average decrease of elevation of $53 \mathrm{~m} \cdot \mathrm{km}^{-1}$, while towards the south, it is only $6.5 \mathrm{~km}$, so in this direction, the parameter is more than twice higher $\left(112 \mathrm{~m} \cdot \mathrm{km}^{-1}\right)$.

The Gorce Mts. massif has a horn-like structure. It means ridges spread from the highest central point in several directions, along which elevations are evened out, and ridge tops are domed and reach similar elevations. The longest ridge, starting from the main culmination of Mt Turbacz, goes eastwards to Mt Gorc and then declines to the north to the Kamienica River valley. It is almost $18 \mathrm{~km}$ long. The shortest ranges, going towards the south, are slightly longer than $4 \mathrm{~km}$. Rock crags are frequently occurring on slopes, adding variety to the Gorce Mts. relief (Alexandrowicz, 1982).

In the southern-eastern part of the massif, the Luban Range is separated from the main horn-like structure. With the main part of the massif, it borders via the Ochotnica River valley, and south of the Knurowska Pass, via Knurowski Stream. This range goes in a latitudinal direction, and its main ridge does not reach high denivelations (like others in the Gorce Mts.). 


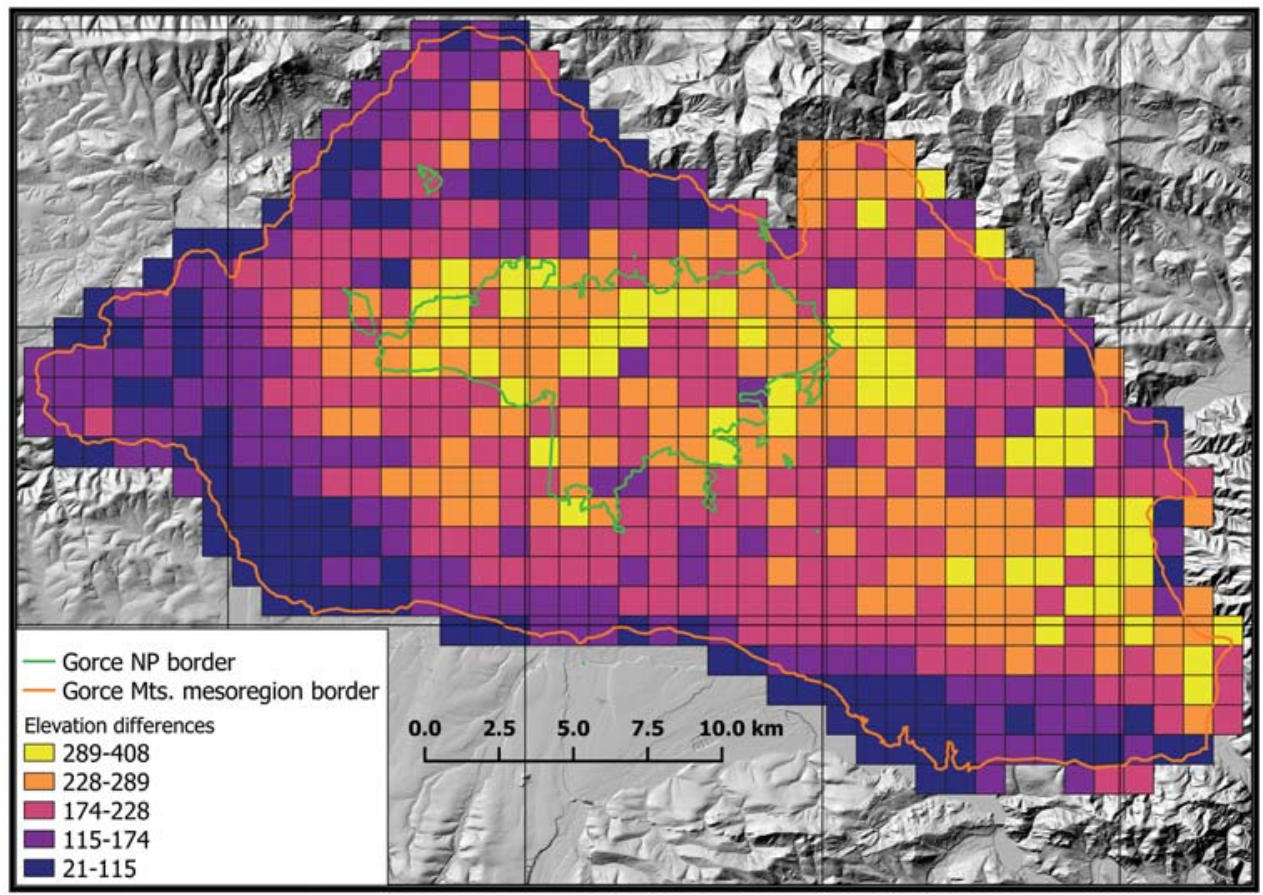

Figure 7. Elevation differences calculated in $1 \times 1 \mathrm{~km}$ square network

Source: Authors' own work based on SRTM digital elevation model (30 m spatial resolution).

The highest parts of the massif are classified as medium mountains relief type, while the northern and western Gorce fragments are considered foothill relief type (Starkel, 1972; Izmaiłow et al., 1995). The arrangement of valleys is diverse and interesting. The highest sections of the main watercourses (Ochotnica, Kamienica, Lepietnica, Obidowiec) pass latitudinally, the pattern seldom encountered in the Polish part of the Western Carpathians, while it is typical of the Beskid Niski and Bieszczady Mts. Significant changes in the main valleys' course directions are also not typical of the Beskidy Mts. valleys. Obidowiec and Lepietnica rivers at the eastern Gorce Mts. boundary change direction from west to south, and the Kamienica river turns first eastwards, then to the north. In the central course, it changes direction again to the south-southeast.

Southern slopes of the Gorce Mts., in particular, the Lubań Range and slopes of the
Czarnotówka - Księży Wierch ridge, feature short and deep V-shaped valleys opening directly to the foreground of the mountain. The northern slopes of the massif valleys merge into bigger streams, forming the river network more typical of the Beskidy Mts.

\section{Contemporary morphogenetic processes}

Contemporary morphogenetic processes in this part of the Carpathians have been studied in the 1950s, which is proved by pioneering papers of Dylikowa (1956) and Gerlach (1960). Tadeusz Gerlach played a unique role in this research field, initiating the establishment of experimental areas, within which he carried out comprehensive monitoring of surface processes (Gerlach, 1966, 1976). The latter quoted paper covered the Gorce Mts. by its reach, namely a Jaszcze River valley fragment. Brzozowski (1996) was among 
the first authors who performed a preliminary typology of surface processes in a selected area of the Gorce Mts. This author, when analyzing surface processes in the Łopuszna River valley, separated denudation and accumulation processes. In denudation processes, he included surface-wash, tree uprooting, mass movements, and erosion.

\section{Landsliding and related processes}

Studies on Gorce landslides were carried out for a long time, but they were never comprehensively analyzed in the entire massif. The area of Gorce Mts. is covered by a detailed geological map in the 1: 50,000 scale (SMGP - Detailed Geological Map of Poland; Scheets Rabka 1032 - Paul \& Ryłko, 1984; Mszana Górna 1033 - Burtan, 1974; Łacko 1034 - Paul, 1978; Nowy Targ 1049 - Watycha, 1975; Szczawnica-Krościenko 1050 - Kulka et al., 1987). The core of the massif was mapped and included in the Mszana Górna 1003 sheet (Burtan et al., 1978), on which landslide areas are marked. Areas considered subject to landsliding in 1953-74 (period of field survey) were determined mostly correctly, but not sufficiently. The actual total area of landslides in those mountains is much larger. The most recent survey carried out by one of the present authors (Kroh, 2018, unpublished materials) confirmed that landslides cover 1285 ha of the Gorce National Park. In contrast, according to the SMGP (Burtan et al., 1978), the landslide affected area is approx. 660 ha. Such a big difference resulted from the work methodology, the focus of mapping teams on geological and not geomorphological surveys (specific landforms), and from strong afforestation of the ground, making delimitation of large landslides difficult. Landslides in the area of Gorce Mts. situated outside of the national park were mapped under the Landslide Counteracting System (SOPO) program by the Polish Geological Institute - National Research Institute (PIG-PIB). The area of all Gorce municipalities was mapped in 2009-2012 (Jurewicz et al., 2009, 2012; Konon et al., 2009; Lewandowski et al., 2010; Olszak \& Kaczmarczyk, 2011;
Rubinkiewicz et al., 2012). A map of landslides resulting from precise ground model analyses based on airborne laser scanning and field verification (Fig. 8) is the last comprehensive study performed within the park boundaries (Kroh, 2018; unpublished data). If added to the SOPO data, this information results in the complete landslide coverage of the entire Gorce Mts. area (Fig. 9).

Numerous researchers were studying the Gorce landslides in detail. Zbójnicka Jama cave in Jaworzyna Kamienicka was interpreted as a dilatational fissure, being an example of an initial stage of landslide slope development (Margielewski \& Urban, 2000, 2003). Wrońska (2006) and Wrońska-Wałach et al. (2013) drew attention to the significant role of landslides in the formation of headwaters. Based on the studies in Gorce, these authors introduced a headwater landslide type, noting a specific shaping of its edges and their different morphodynamic functioning.

Shallow landslide susceptibility has been researched in Jaszcze and Jamne River valleys (Zydroń et al., 2016). Implementation of soil parameters into two GIS models (SINMAP and Iverson) gave accurate results. Validation of the models by implementing the empirical data containing shallow landslides mapped after heavy rainfall in 1997 showed quite a good accuracy of the models. The SINMAP model reached 77\% accuracy, whereas Iverson's model correctly indicated $69 \%$ of landslides. These models have also been used to analyze slope stability. Results suggest that landslide susceptibility in the Jaszcze and Jamne River valley is much higher than estimated by the SOPO project mentioned above (Zydroń et al., 2018).

Lakes and peat bogs within Gorce landslides are a vital source of information on this land's natural history. The sequence of deposits from Lake Iwanowskie (Bucała et al., 2014) allowed to find evidence of human impact on the environment in this area. The oldest deposits were dated for $2.49 \mathrm{ka} \mathrm{BP}$, signs of first farming cultures were dated for 590 770 cal AD. Landslides fen deposits have also been dated in Lubań, Gorc, Kudłoń, 


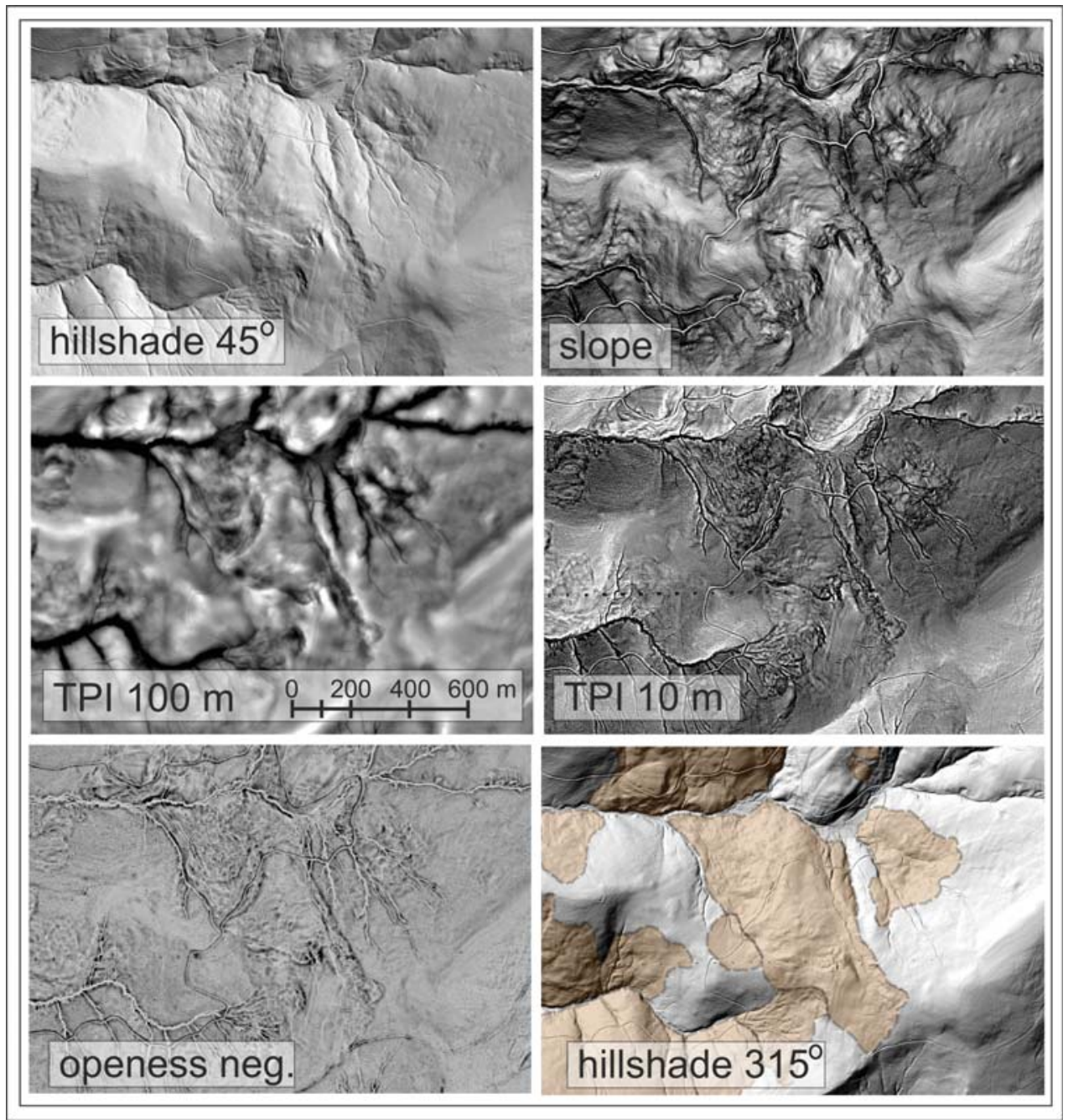

Figure 8. Examples of different raster analysis as a base for relief interpretation. Presented rasters: hillshade with light angle 45 and 315 degree, slope map, TPI - topographic position index with two distances of neighborhood, openness negative index. On the hillshade $315^{\circ}$ range of landslides are marked.

and Turbacz massifs. The relation between climate changes and the development of landslides during the Holocene was specified. The oldest fen deposits are 9500 \pm 90 BP years old $(11,143-10,653$ cal BP) and were found in the Turbacz Range (Buczek, 2019). The next landslide phase was confirmed by wood fragments sampled from the landslide beneath the Góra Gębowa peak (8850 \pm 100 BP, 9739 cal BP) (Kroh et al., 2021). The subsequent phase of the landslide formation was confirmed by data from Jaworzyna Kamienicka (8060 \pm 100 BP, 8949 cal BP - Kroh et al., 2021) and Zawadowskie Lake (7947-7685 cal BP, Buczek, 2019). These phases are linked with the increase of humidity and climate cooling in the Western Carpathians reported by many researchers based on various proxy data (Starkel, 1997; Alexandrowicz 


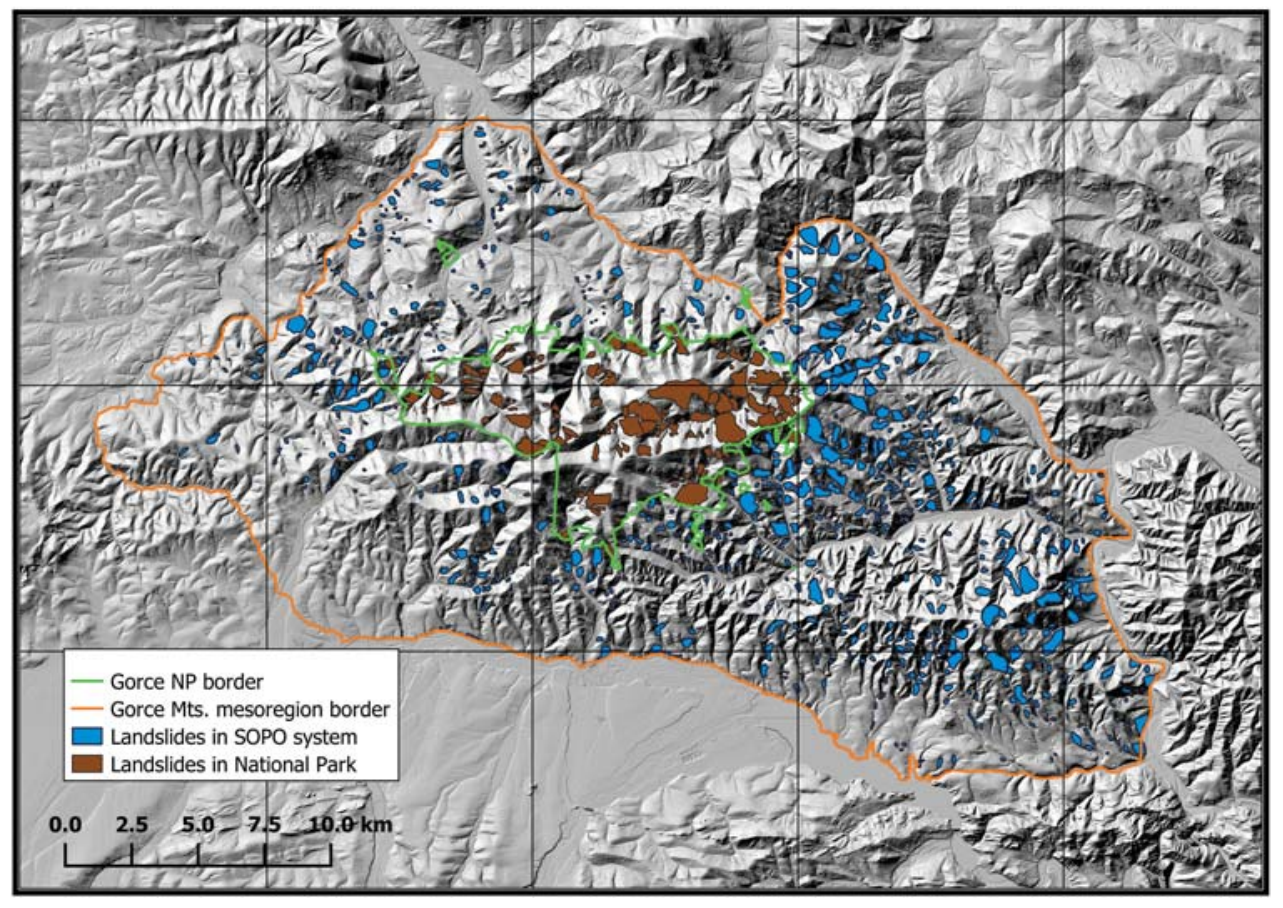

Figure 9. Landslides in the Gorce Mts.

Source: Data outside of the national park area are from the Landslide Counteracting System (SOPO), and within the national park are based on the authors' own work.

\& Alexandrowicz, 1999; Margielewski, 2006, 2018; Haczewski \& Kukulak, 2004). The increase of climate humidity was also noted for about $4.2 \mathrm{ka} \mathrm{BP}$, and cooling between 3.5 and $2.5 \mathrm{ka} \mathrm{BP}$ (Kroh et al., 2021).

The most recent data suggest $\sim 11.1 \mathrm{ka}$ cal $\mathrm{BP}$, $\sim 9.7 \mathrm{ka}$ cal BP, 8.6-8.0 ka cal BP, $\sim 6.0 \mathrm{ka}$ cal BP and $\sim 4.5 \mathrm{ka}$ cal BP, 3.3-2.5 $\mathrm{ka}$ cal BP and $1.75-1.35 \mathrm{ka}$ cal BP as the periods of intensified landslide activity in the Gorce Mountains during the Holocene (Margielewski, 2018; Buczek, 2019; Kroh et al., 2021).

Landslide processes strongly impact the development of small mountain river valleys as well. The relation between landslides and stream channels was analyzed in seven catchments in the Gorce Mts. (Caputa \& Gorczyca, 2020). The percentage of the area affected by the landslides was between 5.5$43 \%$ in these catchments, so it differs very strongly. Influence of the landslides on the channels in the whole Polish Carpathians (30 catchments) is defined as seven types: occlusion, partial occlusion, riparian, cutting colluvium, obliteration, blockade, buffered (Caputa \& Gorczyca, 2020).

Trees uprooting, biotransport, and weathering processes

The process of tree uprooting was one of the most important ones indicated in the Gorce Mts. by Gerlach (1966); he first studied its effects in the 1950s within Hala Długa (Gerlach 1960). Because of a large percentage of forested areas, the impact of tree uprooting is widely observed, but so far, it was not comprehensively analyzed within the entire Gorce Mts. This process significantly affects biotransport (and thereby mechanical denudation of hillslopes), weathering processes within the regolith, and soil profile development. As suggested by the formation 
of pit-mound microtopography (i.e., mounds and pits resulting from tree throw and degradation of the fallen tree trunks), this process can modify the hillslope microrelief for hundreds of years. Such effects were observed and analyzed on Hala Długa, the montane meadow close to Mt Turbacz, and in the Turbacz Reserve (Pawlik \& Kasprzak, 2018; Pawlik \& Šamonil, 2018). In these cases, electrical resistivity measurements and soil analyses showed a significant impact of trees on weathering processes, both within root systems of living trees and places disturbed by tree uprooting (tree throw pits and mounds formed after uprooting). Increased moisture content within root systems and tree throw pits is the parameter indicating a potential intensification of weathering processes. Such effects may be permanent on a scale from $10^{1}$ to $10^{2}$ years, affecting weathering and soil processes (e.g., leaching) in places occupied by trees and transformed by their root systems (Pawlik \& Kasprzak, 2018). Pit-mound microtopography within Hala Długa is a unique example of geomorphic forms created by a synergistic impact of biotic and abiotic factors. Trees in this place were most likely damaged by a strong wind (Gerlach, 1960) at the beginning of the 19th century, indicated by radiocarbon dating and historical maps analysis (Pawlik et al., 2019). Such forms should be protected due to their scientific values. Forms studied within Hala Długa is the only documented example of pit-mound microtopography within a mountain range of southern Poland, developed due to forest disturbance but currently existing within a high montane meadow. This type of pit-mound microrelief was also studied in the Stołowe Mts., the Middle Sudety Mts., but there it exists within a forested hillslope (Pawlik et al., 2013).

\section{Fluvial processes and landforms}

The functioning of river channels and valley bottoms in the Gorce Mts. was also considered from several viewpoints. In the Kamienica river valley, the transport of woody debris and its impact on the geomorphology of the stream channel was analyzed. More than 1600 tree trunks were localized in the channel in the section of the initial eight kilometers of the stream (Kaczka, 2009). They caused the formation of log jams and accumulation of rock material in front of them, affecting the stream's fluvial energy. Because the channel width in the upper section of Kamienica is much smaller than the height of trees fallen to it, their transport is limited.

Consequently, woody debris is deposited in the narrower channel segments (Wyżga et al., 2012, 2015). The accumulation of bed material on the upstream side of log jams forces the channel bed aggradation and results in a characteristic stepped longitudinal stream profile in Kamienica Valley (Wyżga et al., 2003). The formation and longevity of log jams depend primarily on the flood frequency. In connection with coarse woody debris, river high water levels result in significant changes in the intensity of accumulation and erosion processes within the channel banks and its bottom. Coarse woody debris deposited on gravel bars makes them permanent and facilitates vegetation entering their area (Kaczka, 1999).

During the last decade, also accumulative effects of beavers activity are observed in the Gorce National Park area. These animals build dams that act as natural sedimentation traps in axes of mountain watercourses. However, this issue still awaits its scientific study.

The role of floods in shaping streams relief was analyzed in Jaszcze and Jamne River valleys (Niemirowski, 1972, 1974; Bucała, 2010; Bucała et al., 2016). The most remarkable transformations of stream channels during floods were caused by lateral erosion. It is a dominating process as compared with deep erosion. Log jams are an additional element increasing the extent of lateral erosion by forcing changes in the high water flow direction. Floods also result in the formation of new gravel bars and upbuilding of the old ones. Places eroded during floods prevail over the aggraded ones (Bucała, 2010). During the high water level, the downcutting and intensive riverbed erosion was recorded in the upper valley sections, while in the central and lower sections, riverbed and lateral 
erosion and aggradation. Also, fluvial material redeposition plays a significant role (Bucała et al., 2016). In the recent decades at the Ochotnica valley, two periods of channel development was discovered. Between 1976 and 1996, aggradation was the predominant process, whereas from 1997 to 2011, incision dominated (Kijowska-Strugała \& Bucała-Hrabia, 2019).

Krzemien (1984), as the first, was drawing attention to the domination of deep erosion in streams on northern slopes of the Gorce Mts. He noticed such consequences of the environmental-social transformations of the Gorce watersheds as channel transformation to narrower and much deeper, floodplains became inactive, gravel stream banks and stream beds became fixed and rock outcrops appeared in alluvial sections.

Płaczkowska (2014) statistically analyzed the relationship between geological bedrock and morphometric properties of headwater areas in the Lubań Range. She found no significant differences between the headwater areas built of various rock formations or related to the rock strata strike. The only factor that impacts the variability of higher headwater areas is neotectonic activity. The headwater areas within the bedrock segments elevated due to the neotectonic activity are much larger and slightly longer than other headwater areas within the Lubań Range. Recent geomorphic activity in forest-covered headwater catchments was a subject of numerous studies (Wrońska-Wałach, 2009, 2014; Morawska \& Wrońska-Wałach, 2012). Based on the treering record from the exposed roots of Picea abies, Wrońska-Wałach $(2009,2014)$ found evidence of the frequency of various erosional processes induced by rainfall episodes.

Mouth sections of Kamienica and Ochotnica streams were characterized according to terrace levels development and valley bottom formation (Olszak, 2011). In the valley bottom relief, seven terrace levels were documented, and the development of terraces relief allowed to show their evolution stages. They were classified as complexresponse terraces. In the interglacial periods, valleys were eroded and deepened. In turn, in glacial periods, when periglacial conditions characterized this area, intensive solifluction, physical weathering, and debris flow activity on slopes caused large amounts of material supply to the fluvial systems, and its accumulation in river beds (Olszak \& Karczewski, 2008; Olszak, 2011). Terraces development also shows that the massif was uplifted during the entire Quaternary period.

Bedload transport was analyzed in the Gorce mountains' rivers as well. Such analyses were made in streams: Młynne (Radecki-Pawlik et al., 2019) Porębianka (Plesiński, 2018; Korpak 2007), Mszanka (Korpak, 2007; Korpak et al., 2008), Jaszcze and Jamne (Bucała \& RadeckiPawlik, 2011; Radecki-Pawlik et al., 2014). These analyses were performed in natural, trained, and dammed parts of the stream channel. Anthropogenic factors have a considerable influence on streams functioning nowadays. The most affecting human-origin channel changes are gravel mining and channel training. Mountain stream boulders are very often both legally and illegally mined from riverbeds, which is disastrous for the fluvial state of rivers and river ecology (Radecki-Pawlik et al., 2019). Stream regulations generate lower delivery of rock material from the river banks (Bucała \& Radecki-Pawlik, 2011). Mostly because of gravel mining and bank protection, the amount of bedload available for fluvial transport has been considerably reduced. On man-changed parts of the streams, a significant reduction in the number and area of alluvial forms was noted (Korpak, 2007). Hydrotechnical regulations led to the narrowing, shortening, and straightening of the watercourse channel. As an effect, channel gradient increased, and such hydrodynamic parameters as mean velocity and shear stress were higher than those in the unregulated parts (Radecki-Pawlik et al., 2014; Korpak, 2007). Reduction of alluvial sections and increase of erosional ones, and acceleration of channel downcutting follow these changes. Also, the elongation of sections where the channel incised to the bedrock was observed. Such occurrence was noted on streams: Jaszcze 
(Bucała \& Radecki-Pawlik, 2011), Mszanka, and Porębianka (Korpak, 2007). All researchers who examined the Gorce mountains' rivers conclude that the influence of hydrotechnical engineering is very strong and has a negative effect on the streams' geomorphological and hydroecological conditions (Korpak et al., 2007; Korpak, 2012; Radecki-Pawlik et al., 2012; Bucała \& Radecki-Pawlik, 2011; Radecki-Pawlik et al., 2014; Plesiński, 2018).

\section{Human impact on landforms and geomorphic processes}

Anthropogenic impact on the relief was analyzed from the viewpoint of roads and tracks development and functioning. Some aspects of human impact on fluvial forms and processes were shorty reviewed in the previous section.

Touristic trails and their degradation level were mapped in 2007-2009 over a distance of $55 \mathrm{~km}$ (Tomczyk \& Ewertowski, 2011). Among the mapped parameters (such as trail width, incision, number of abandoned sections, and others), the most crucial variable indicating degradation of the tourist trails was an increase of trail width (from 0.3 to $24.5 \mathrm{~m}, 2.4 \mathrm{~m}$ on average) (Tomczyk \& Ewertowski, 2011). The tracks with an uneven tread surface are the most prone to erosion. Due to intensive tourist traffic, some trails are evened, which helps to prevent erosion. Simultaneously, uneven paths are a subject of widening due to accelerated deterioration by tourists who bypass uncomfortable to pass places and destroy microforms on the trails. Three main factors influence soil erosion along trails: soil properties (soil bulk density, texture, etc.), the tracks' morphology, and local geomorphological conditions especially slope length above eroded places. The most sensitive parts of tourist trails are the bottom parts of local slopes (Tomczyk \& Ewertowski, 2013a). Results on soil erosion along tourist trails can be implemented to minimize tourists' impact on the natural environment (Tomczyk et al., 2013b, 2017).

Impact of the road network development on the formation of tourist tracks
(Wałdykowski, 2005), as well as geomorphic activity along forest and field roads was also studied (Wałdykowski, 2006; Wałdykowski \& Krzemień, 2013). These results show that roads and tracks are among the most morphodynamically active zones in the Gorce Mts. and have a significant role in the hillslope relief formation, soil erosion, and transport. The protection provided by the Gorce National Park is supported by the fact that soil erosion along roads is significantly more active outside the park boundaries, where forest management is carried out. Also, the traffic of cars, quads, and motorcycles is much heavier there. Wałdykowski (2006) found the impact of hiking is smaller than other factors. A similar issue, i.e., the environmental sensitivity to tourist tracks functioning, was determined using a geo-IT model (spatial model implemented into GIS software). In this model, the topography, the soil type, the plant community, land use, and land cover were considered (Tomczyk, 2011). The results showed significant susceptibility of tourist trails to erosion in the northern part of the park, where hillslopes are much steeper than in other regions. High vulnerability to changes exists in more than $46 \%$ of the park area. The model indicated another 39\% as areas of medium susceptibility to erosion.

Land use and land cover changes are a critical factor in mountain geomorphology evolution. This aspect of the Gorce environment was studied in the Ochotnica valley, particularly in Jaszcze and Jamne sub-valleys (e.g., Bucała, 2014, 2015a; Bucała-Hrabia, 2017, 2018). Land-use changes, i.e., increasing forest cover, the proportion of built areas, etc., caused agricultural landscapes' transition to uncultivated areas (Bucała, 2014). This was followed by changes in soil properties and plant communities' structure (Bucała et al., 2015). The most common anthropogenic landforms were agricultural terraces and the road network. Analyses of road density changes were also performed in Jaszcze and Jamne valleys (Bucała, 2012, 2015b). In these catchment areas, it was found that the amount of roads is so high that they 
constitute a draining network of main slopes, fulfilling the function of both run-off concentration and drains accelerating the surface flow. An average road density exceeds twice the natural streams network. Also, in this area, it was noticed that the log skidding causes much faster linear erosion of roads.

Agricultural terraces are anthropogenic microforms commonly occurring in the Gorce Mts. area, apart from roads. They exist on the majority of slopes, which were agriculturally used. They result in the local reduction of slope gradient and constitute a local erosion basis, stopping ca $40 \%$ of the soil material displaced due to washing (Bucała, 2012, 2017, after Gerlach, 1966). Agricultural terraces and old arable fields' edges are the places where stone mounds occur. In the course of traditional farming works, stones that obstructed the farming were thrown over the edge of the fields. As a result, mounds of stones were formed. These mounds are common in areas where historic traditional farming has been noted. These features are often observed but still poorly studied anthropogenic landforms.

\section{Summary and conclusions}

The level of recognition of the activity of geomorphic processes in the Gorce Mts. suggests the next steps should be taken towards research work on the massif's contemporary morphodynamics. This also applies to the long-term evolution of the entire area. Taking into account the up-to-date results of geomorphic studies that have been conducted so far, the following issues should be covered by future studies on landforms and surface processes of the Gorce Mts. mesoregion:

1. landscape evolution on the whole Cenozoic scale, based on results of geochronological (10Be dating), palaeobotanical, and palaeopedological analyses;

2. studies on geodynamics and neotectonics based on geomorphometric and geophysical techniques (fault zones exploration);

3. measurement and permanent monitoring of contemporary morphogenetic processes in the hillslope, valley, and channel systems (including biogeomorphological studies);

4. studies on structural control of various landforms development (e.g., by studying the rock hardness);

5. comprehensive studies on landslides age and genesis.

\section{Acknowledgements}

The authors warmly thank the Management of the Gorce National Park for their consent to carry out field studies in the years 20162018 and for making the spatial data available by the Park Scientific-Educational Laboratory. The authors work so far was carried under grants of the National Science Centre: Miniatura (No 2017/01/X/ST10/00060; PK) and Sonata (No 2014/15/D/ST10/04123; ŁP). The authors also thank two anonymous Reviewers and the Editor for many constructive comments which have improved this paper.

\section{Editors' note:}

Unless otherwise stated, the sources of tables and figures are the authors', on the basis of their own research.

\section{References}

Alexandrowicz, Z. (1982). Skałki piaskowcowe Gorczańskiego Parku Narodowego. Ochrona Przyrody, 44, 293-316.

Alexandrowicz, S.W., Alexandrowicz, Z. (1999). Recurrent Holocene landslides: A case study of the Krynica landslide in the Polish Carpathians. The Holocene, 9(1): 91-99.

https://doi.org/10.1191/095968399674419966 
Balon, J., Jodłowski, M. (2014). Regionalizacja fizycznogeograficzna Karpat Zachodnich - studium metodologiczne. In W. Ziaja, M. Jodłowski (Eds.), Struktura środowiska przyrodniczego a fizjonomia krajobrazu (pp. 85-105). Kraków: Instytut Geografii i Gospodarki Przestrzennej UJ.

Brzozowski, S. (1966). Beskidy Zachodnie (450.4). In J. Kondracki (Ed.), Sympozjum w sprawie regionalizacji fizycznogeograficznej Polski i krajów sqisiednich, Przewodnik wycieczki PTG, Warszawa, 17, 19.

Bucała, A. (2009). Rola opadów nawalnych w kształtowaniu stoków i koryt w Gorcach na przykładzie zlewni potoków Jaszcze i Jamne. Przegląd Geograficzny, 81, 3, 399-418.

Bucała, A. (2010). Morphological role of floods in the shaping of stream channels in the Gorce mountains (exemplified by Jaszcze and Jamne stream valleys). Geomorphologia Slovaca et Bohemica, 10(1), 45-54.

Bucała, A. (2012). Współczesne zmiany środowiska przyrodniczego dolin potoków Jaszcze i Jamne w Gorcach. Prace Geograficzne, 231, Warszawa: Instytut Geografii i Przestrzennego Zagospodarowania PAN.

Bucała, A. (2014). The impact of human activities on land use and land cover changes and environmental processes in the Gorce Mountains (Western Polish Carpathians) in the past 50 years. Journal of Environmental Management, 138, 4-14. https://doi.org/10.1016/j.jenvman.2014.01.036

Bucała, A. (2015a). Land use/cover changes related to transition from communist system to free market economy in the Gorce Mts., Polish Carpathians, Poland. Forest, 66(43.32), 79-83.

Bucała, A. (2015b). Wpływ działalności człowieka na przekształcenia krajobrazów górskich w Gorcach. Prace Komisji Krajobrazu Kulturowego 29, 23-37.

Bucała-Hrabia, A. (2017). Long-term impact of socio-economic changes on agricultural land use in the Polish Carpathians. Land Use Policy, 64, 391-404. http://dx.doi.org/10.1016/j.landusepol.2017.03.013

Bucała-Hrabia, A. (2018). Land use changes and their catchment-scale environmental impact in the Polish Western Carpathians during transition from centrally planned to free-market economics. Geographia Polonica, 91(2), 171-196. https://doi.org/10.7163/GPol.0116

Bucała, A., Radecki-Pawlik, A. (2011). Wpływ regulacji technicznej na zmiany morfologii górskiego potoku: potok Jamne, Gorce. Acta Sci. Pol., Formatio Circumiectus, 10(1), 3-16.

Bucała, A., Margielewski, W., Starkel, L., Buczek, K., Zernitskaya, V. (2014). The reflection of human activity in the sediments of Iwankowskie Lake from Subatlantic Phase (Polish Outer Carpathians). Geochronometria, 41(4), 377-391. https://doi.org/10.2478/s13386-013-0172-z

Bucała, A., Budek, A., Kozak, M. (2015). The impact of land use and land cover changes on soil properties and plant communities in the Gorce Mountains (Western Polish Carpathians), during the past 50 years. Zeitschrift für Geomorphologie, Supplementary Issues, 59(2), 41-74.

https://doi.org/10.1127/zfg_suppl/2015/S-59204

Bucała, A., Budek, A., Kozak, M., Starkel, L., Wiejaczka, Ł. (2016). Kierunki przemian środowiska przyrodniczego dolin gorczańskich. Warszawa: Instytut Geografii i Przestrzennego Zagospodarowania PAN im. Stanisława Leszczyckiego.

Buczek, K. (2019). Dating landslides in the Gorce Mts. (Polish Outer Carpathians) - preliminary results. Geological Quarterly, 63(4). https://dx.doi.org/10.7306/gq.1501

Buczek, K., Górnik, M. (2019). Aktywność neotektoniczna Pasma Lubania (Gorce) na podstawie analizy parametrów morfometrycznych. Przegląd Geologiczny, 67(4), 270-278.

https://doi.org/10.7306/2019.24

Burtan, J., Paul, Z., Watycha, L. (1976). Szczegółowa Mapa Geologiczna Polski w skali 1:50,000, Arkusz Mszana Górna 1033. Warszawa: Wydawnictwa Geologiczne.

Burtan, J., Paul, Z., Watych, L. (1978). Arkusz Mszana Górna (1033). Objaśnienia do SMGP w skali 1:50000. Warszawa: Wydawnictwa Geologiczne.

Caputa, J., Gorczyca, E. (2020). The role of landslides in the evolution of a small mountain river valley (Polish Carpathians). Episodes. https://doi.org/10.18814/epiiugs/2020/020078 
Chwistek, K., (2001). Dynamics of tree stands in the Gorce National Park (southern Poland) during the period 1992-1997. Nature Conservation, 58, 17-32.

Cieszkowski, M., Ślączka, A., Wdowiarz, S. (1985). New data on structure of the Flysch Carpathians. Przeglad Geologiczny, 33(6), 313-329.

Cieszkowski, M. Chodyń, R., Szczęch, M. (2015). Gorce - góry fliszowe. In P. Czarnota, M. Stefanik (Eds.) Gorczański Park Narodowy - przyroda i krajobraz pod ochrona (pp.39-51). Poręba Wielka - Kraków: Gorczański Park Narodowy.

Dylikowa, A. (1956). Formes contemporaines du type congélifluctif sur le Turbacz (Gorce - Carpates). Biuletyn Peryglacjalny, 4, 175-188.

Forma, A., Zuchiewicz, W. (2001). Morfotektonika Gorców (polskie Karpaty Zachodnie) w świetle wybranych wskaźników morfometrycznych. In W. Zuchiewicz (Ed.), Materiały IV Ogólnopolskiej Konferencji "Neotektonika Polski": Neotektonika, morfotektonika, sejsmotektonika - stan badań i perspektywy rozwoju (pp. 41-46). Kraków: Komisja Neotektoniki Komitetu Badań Czwartorzędu PAN.

Forma, A., Zuchiewicz W. (2002). Morphotectonics of the Gorce Mountains, Western Outer Carpathians. Folia Quaternaria 73, 69-78.

Gerlach, T. (1960). W sprawie genezy kopczyków ziemnych na Hali Długiej w Gorcach. Przegląd Geograficzny, 32(1-2), 86-93.

Gerlach, T. (1966). Współczesny rozwój stoków w dorzeczu górnego Grajcarka (Beskid Wysoki - Karpaty Zachodnie). Warszawa: Wydawnictwa Geologiczne.

Gerlach, T. (1976). Współczesny rozwój stoków w Polskich Karpatach Fliszowych. Wrocław: Zakład Narodowy im. Ossolińskich.

Gilewska, S. (1986). Podział Polski na jednostki geomorfologiczne. Przeglad Geograficzny, 58(1-2), 15-40.

Haczewski, G., Kukulak, J. (2004). Early Holocene landslide-dammed lake in the Bieszczady Mountains (Polish East Carpathians) and its evolution. Studia Geomorphologica Carpatho-Balcanica, 38, 83-96.

Izmaiłow, B., Kaszowski, L., Krzemień, K., Święchowicz, J. (1995). Rzeźba In J. Warszyńska (Ed.), Karpaty Polskie. Przyroda, człowiek i jego działalność (pp. 23-30). Kraków: Wydawnictwo UJ.

Jarosz, S. (1935). Badania geograficzno-leśne w Gorcach. Prace Rolniczo-Leśne PAU 16, 1-125.

Jurewicz, E., Kaczorowski, J., Klimkiewicz, D., Konon, A., Ludwiniak, M., Ozimkowski, ... Tomaszczyk, M. (2009). Mapa osuwisk i terenów zagrożonych ruchami masowymi w skali 1:10,000, gm. Mszana Dolna, pow. limanowski, woj. małopolskie.

Jurewicz, E., Ozimkowski, W., Rubinkiewicz, J., Śmigielski, M., Tomaszczyk, M., Cybulska, D., Stachowska, A., Stępczak, P. (2012). Mapa osuwisk i terenów zagrożonych ruchami masowymi w skali 1:10,000, gm. Ochotnica Dolna, pow. nowotarski, woj. małopolskie.

Kaczka, R.J. (1999). Rola kłód w kształtowaniu systemu fluwialnego i zwiq̨zanych z nim biocenoz (Kamienica, Gorce). In W. Chełmicki, J. Pociask-Karteczka (Eds.), Interdyscyplinarność w badaniach dorzecza (pp. 245-251). Kraków: Instytut Geografii UJ.

Kania, M., Szczęch, M., (2020). Geometry and topology of tectonolimeaments in the Gorce Mts. (Outer Carpathians) in Poland. Journal of Structural Geology, 141, 104186. https://doi.org/10.1016/j.jsg.2020.104186

Kaczka, R.J. (2009). Dynamics of large woody debris and wood dams in mountain Kamienica Stream, Polish Carpathians. TRACE-Tree Rings in Archaeology, Climatology and Ecology 7, 27-30. https://doi.org/10.2312/GFZ.b103-09038

Kijowska-Strugała, M., Bucała-Hrabia, A. (2019). Flood types in a mountain catchment: The Ochotnica River, Poland. Acta Geographica Slovenica, 59, 24-36. https://doi.org/10.3986/AGS.2250.

Klimaszewski, M., Starkel, L. (1972). Karpaty Polskie. In M. Klimaszewski (Ed.), Geomorfologia Polski, 1 (pp. 21-115). Warszawa: PWN,.

Konon, A., Rubinkiewicz, J., Śmigielski, M., Klimkiewicz, D., Tomaszczyk, M. (2009). Mapa osuwisk i terenów zagrożonych ruchami masowymi w skali 1:10,000, gm. Niedźwiedź, pow. limanowski, woj. małopolskie. 
Korpak, J. (2007). The influence of river training on mountain channel changes (Polish Carpathian Mountains). Geomorphology, 92(3-4), 166-181. https://doi.org/10.1016/j.geomorph.2006.07.037

Korpak, J., Krzemien, K., Radecki-Pawlik, A. (2008). Wpływ czynników antropogenicznych na zmiany koryt cieków karpackich. Infrastruktura i ekologia terenów wiejskich, (04).

Korpak, J. (2012). Morfologia i funkcjonowanie uregulowanego koryta rzeki górskiej - na przykładzie Mszanki w Gorcach. Przykład opracowania (Morphology and functioning of regulated mountain river channel - Mszanka River in the Gorce Mts.). Case study). In K. Krzemień (Ed.), Struktura koryt rzek i potoków (studium metodyczne) (pp. 89-101). Kraków: Instytut Geografii i Gospodarki Przestrzennej UJ.

Kroh, P. (2018). Mapa osuwisk Gorczańskiego Parku Narodowego [Unpusblished manuscript].

Kroh, P., Okupny, D., Bryndal, T., Kondracka, M., Cybul, P. (2021). Holoceńskie okresy intensyfikacji procesów stokowych w Gorcach - porównanie najnowszych wyników badań. Przeglad Geograficzny, 94(1), (in press).

Krzemień, K. (1984). Współczesne zmiany modelowania koryt potoków w Gorcach. Zeszyty Naukowe UJ, Prace Geograficzne, 59, 83-96.

Książkiewicz, M. (1972). Budowa geologiczna Polski, vol. 4, Tektonika. 3. Karpaty.Warszawa: Wydawnictwa Geologiczne.

Kulka, A., Rączkowski, W., Żytko, K., Gucik, S., Paul, Z. (1987). Szczegółowa Mapa Geologiczna Polski w skali 1:50000, Arkusz Szczawnica-Krościenko 1050. Warszawa: Wydawnictwa Geologiczne.

Lewandowski, J., Wojciechowski, T., Salomon, T. (2010). Mapa osuwisk i terenów zagrożonych ruchami masowymi w skali 1:10,000. gm. Rabka-Zdrój, pow. nowotarski, woj. małopolskie.

Margielewski, W. (1998). Landslide phases in the Polish Outer Carpathians and their relation to climatic changes in the Late Glacial and the Holocene. Quaternary Studies in Poland, 15(5), 37-53.

Margielewski, W. (2006). Records of the Late Glacial-Holocene palaeoenvironmental changes in landslide forms and deposits of the Beskid Makowski and Beskid Wyspowy Mts. area (Polish Outer Carpathians). Folia Quaternaria, 76, 149-149.

Margielewski, W. (2018). Landslide fens as a sensitive indicator of paleoenvironmental changes since the Late Glacial: a case study of the Polish Western Carpathians. Radiocarbon, 60(4), 1199-1213. https://doi.org/10.1017/RDC.2018.68

Margielewski, W., Urban, J. (2000). Charakter inicjacji ruchów masowych w Karpatach fliszowych na podstawie analizy strukturalnych uwarunkowań rozwoju wybranych jaskiń szczelinowych. Przeglad Geologiczny, 48(3), 268-274.

Margielewski, W., Urban, J. (2003). Crevice-type caves as initial forms of rock landslide development in the Flysch Carpathians. Geomorphology, 54(3-4), 325-338.

https://doi.org/10.1016/S0169-555X(02)00375-6

Miczyński, J. (2015). Klimat rządzi przyroda. In P. Czarnota, M. Stefanik (Eds.) Gorczański Park Narodowy. Przyroda i krajobraz pod ochrona (pp. 35-38). Poręba Wielka: Gorczański Park Narodowy.

Morawska, M., Wrońska-Wałach, D. (2012). Dendrogeomorphological analysis of gully erosion in different types of landscapes. Examples from Szeskie Hills and Gorce Mountains. In H. Gartner, P. Rozenberg, P. Montes, O. Bertel, G. Helle, I. Heinrich (Eds.), TRACE - Tree Rings in Archaeology, Climatology and Ecology, Potsdam, 119-126. https://doi.org/10.2312/GFZ.b103-12036

Niemirowski, M. (1972). Comparison of the effects of flood in two catchment basins in the Gorce Mts. Studia Geomorphologica Carpatho-Balcanica, 6, 201-203.

Niemirowski, M. (1974). Dynamika współczesnych koryt potoków górskich (na przykładzie potoków Jaszcze i Jamne w Gorcach). Kraków: Uniwersytet Jagielloński, PWN.

Obrębska-Starklowa, B. (1968). Pokrywa śnieżna we wschodniej części Gorców. Zeszyty Naukowe UJ, Prace Geograficzne, 18, 27-53.

Obrębska-Starklowa, B. (1969a). Stosunki mikroklimatyczne na pograniczu pięter leśnych i pól uprawnych w Gorcach. Kraków: Uniwersytet Jagielloński. 
Obrębska-Starklowa, B. (1969b). Mezoklimat zlewni potoków Jaszcze i Jamne. Studia Naturae, Ser. A, 3, 1-102.

Olszak, J. (2009). Evidence for differential crustal uplift between the neighbouring Kamienica and Ochotnica river valleys in the Polish Outer Western Carpathians. Annales Societatis Geologorum Poloniae, 79, 187-193.

Olszak, J. (2011). Evolution of fluvial terraces in response to climate change and tectonic uplift during the Pleistocene: evidence from Kamienica and Ochotnica River valleys (Polish Outer Carpathians). Geomorphology, 129(1-2), 71-78. https://doi.org/10.1016/j.geomorph.2011.01.014

Olszak, J., Karczewski, J. (2008). Usefulness of GPR measurements in interpretation of structures of river terraces (Kamienica River valley, Polish Outer Carpathians). Przegląd Geologiczny, 56(4), 330-334.

Olszak, J., Kaczmarczyk, R. (2011). Mapa osuwisk i terenów zagrożonych ruchami masowymi w skali 1:10,000. gm. Kamienica, pow. limanowski, woj. małopolskie.

Oszczypko, N. (1995). Budowa geologiczna In J. Warszyńska (ed.), Karpaty Polskie. Przyroda, człowiek i jego działalność (pp. 15-22). Kraków: Wydawnictwo UJ.

Oszczypko, N., Oszczypko-Clowes, M. (2011). Stages of development in the Polish Carpathian Foredeep Basin. Central European Journal of Geosciences 4, 138-162. https://doi.org/10.2478/s13533-011-0044-0

Paul, Z. (1978). Szczegółowa Mapa Geologiczna Polski w skali 1:50,000, Arkusz Łącko 1034. Warszawa: Wydawnictwa Geologiczne.

Paul, Z., Ryłko, W. (1976). Szczegółowa Mapa Geologiczna Polski w skali 1:50,000, Arkusz Rabka 1032, Wydawnictwa Geologiczne, Warszawa.

Pawlik, Ł., Migoń, P., Owczarek, P., Kacprzak, A. (2013). Surface processes and interactions with forest vegetation on a steep mudstone slope, Stołowe Mountains, SW Poland. Catena, 109, 203-216. https://doi.org/10.1016/j.catena.2013.03.011

Pawlik, Ł., Kasprzak, M. (2018). Regolith properties under trees and the biomechanical effects caused by tree root systems as recognized by electrical resistivity tomography (ERT). Geomorphology, 300, 1-12. https://doi.org/10.1016/j.geomorph.2017.10.002

Pawlik, Ł., Šamonil, P. (2018). Biomechanical and biochemical effects recorded in the tree root zone - soil memory, historical contingency and soil evolution under trees. Plant and Soil, 426, 109-134. https://doi.org/10.1007/s11104-018-3622-9

Pawlik, Ł., Šamonil, P., Malik, I., Kroh, P., Ślęzak, A., Daněk, P. (2019). Geomorphic edge effects in response to abiotic and anthropogenic disturbances in forest ecosystems of the Gorce Mountains, Western Carpathians. Catena, 177, 134-148. https://doi.org/10.1016/j.catena.2019.02.013

Plesiński, K. (2018). Zmienność układu i morfologii dna rzecznego w rejonie oddziaływania narzutowego bystrza o zwiększonej szorstkości (przykład z rzeki Porębianki). Acta Scientiarum Polonorum, Formatio Circumiectus, 17(1), 89-103.

Płaczkowska, E. (2014). Geological aspects of headwater catchments development in the Lubań Range (the Outer Carpathians, Poland). Zeitschrift für Geomorphologie, 58(4), 525-537. https://doi.org/10.1127/0372-8854/2014/0143

Pomianowski, P. (2003). Tektonika Kotliny Orawsko-Nowotarskiej - wyniki kompleksowej analizy danych grawimetrycznych i geoelektrycznych. Przeglad Geologiczny, 51(6), 498-506.

Radecki-Pawlik, A., Klonowska-Olejnik, M., Florencka, N. (2002). Transport rumowiska, skład jakościowy osadów oraz chemizm wody potoku Młynne w Gorcach (Karpaty polskie). Zeszyty Naukowe Akademii Rolniczej w Krakowie. Inżynieria Środowiska, 22.

Radecki-Pawlik, A., Bucała, A., Plesiński, K., Oglęcki, P. (2014). Ecohydrological conditions in two catchments in the Gorce Mountains: Jaszcze and Jamne streams-Western Polish Carpathians. Ecohydrology \& Hydrobiology, 14(3), 229-242. https://doi.org/10.1016/j.ecohyd.2014.06.003 
Radecki-Pawlik, A., Kuboń, P., Radecki-Pawlik, B., Plesiński, K. (2019). Bed-load transport in two differentsized mountain catchments: Mlynne and Lososina streams, Polish Carpathians. Water, 11(2), 272. https://doi.org/10.3390/w11020272

Rubinkiewicz, J., Karwacki, K., Kwecko, P. (2012). Mapa osuwisk i terenów zagrożonych ruchami masowymi w skali 1:10000, gm. Nowy Targ, pow. limanowski, woj. małopolskie.

Solon, J., Borzyszkowski, J., Bidłasik, M., Richling, A., Badora, K., ... Ziaja, W. (2018). Physico-geographical mesoregions of Poland: verification and adjustment of boundaries on the basis of contemporary spatial data. Geographia Polonica, 91(2), 143-170. https://doi.org/10.7163/GPol.0115

Starkel, L.. (1972). Karpaty Zewnętrzne In M. Klimaszewski (Ed.). Geomorfologia Polski. Vol. 1. Warszawa: PWN.

Starkel, L. (1997). Mass movement during the Holocene: Carpathian example and the European perspective. Rapid mass movement as a source of climatic evidence for the Holocene. Palaeoclimate Research, 19, 385-400.

Szczęch, M., Cieszkowski, M., Chodyń, R., Loch, J. (2016). Geotouristic values of the Gorce National Park and its surroundings (The Outer Carpathians, Poland). Geotourism, 1-2, 44-45. https://dx.doi.org/10.7494/geotour.2016.44-45.27

Tomczyk, A.M. (2011). A GIS assessment and modelling of environmental sensitivity of recreational trails: the case of Gorce National Park, Poland. Applied Geography, 31(1), 339-351. https://doi.org/10.1016/j.apgeog.2010.07.006

Tomczyk, A.M., Ewertowski, M. (2011). Degradation of recreational trails, Gorce National Park, Poland. Journal of Maps, 7(1), 507-518. https://dx.doi.org/10.4113/jom.2011.1195

Tomczyk, A.M., Ewertowski, M. (2013a). Quantifying short-term surface changes on recreational trails: the use of topographic surveys and 'digital elevation models of differences' (DODs). Geomorphology, 183(1), 58-72. https://doi.org/10.1016/j.geomorph.2012.08.005

Tomczyk, A.M., Ewertowski, M. (2013b). Planning of recreational trails in protected areas: application of regression tree analysis and geographic information systems. Applied Geography, 40, 129-139. https://doi.org/10.1016/j.apgeog.2013.02.004

Tomczyk, A.M., Ewertowski, M.W., White, P.C., Kasprzak, L. (2017). A new framework for prioritising decisions on recreational trail management. Landscape and Urban Planning, 167, 1-13. https://doi.org/10.1016/j.landurbplan.2017.05.009

Wałdykowski, P. (2005). Geomorfologiczne aspekty rozwoju ruchu turystycznego w obrębie sieci dróg w Gorcach. Turystyka i Rekreacja, 1, 29-32.

Wałdykowski, P. (2006). Wpływ dróg górskich na dynamikę procesów morfogenetycznych w rejonie Turbacza. Ochrona Beskidów Zachodnich, 1, 67-77.

Wałdykowski, P., Krzemień, K. (2013). The role of road and footpath networks in shaping the relief of middle mountains on the example of the Gorce Mountains (Poland). Zeitschrift für Geomorphologie, 57(4), 429-470. https://doi.org/10.1127/0372-8854/2013/0108

Watycha, L. (1975). Szczegółowa Mapa Geologiczna Polski w skali 1:50,000, Arkusz Nowy Targ 1049. Warszawa: Wydawnictwa Geologiczne.

Wezyk, P., Hawrylo, P., Janus, B., Weidenbach, M., Szostak, M., 2018. Forest cover changes in Gorce NP (Poland) using photointerpretation of analogue photographs and GEOBIA of orthophotos and nDSM based on image-matching based approach. European Journal of Remote Sensing, 51(1), 501-510. https://doi.org/10.1080/22797254.2018.1455158

Wrońska, D. (2006). Wykształcenie i funkcjonowanie lejów źródliskowych potoków gorczańskich. Ochrona Beskidów Zachodnich, 1, 59-65.

Wrońska-Wałach, D. (2009). Dendrogeomorphological analysis of a headwater area in the Gorce Mountains. Studia Geomorphologica Carpatho-Balcanica, 43, 97-114. 
Wrońska-Wałach, D. (2014). Differing responses to extreme rainfall events in headwater areas recorded by wood anatomy in roots (Gorce Mountains, Poland). Catena, 118, 41-54. https://doi.org/10.1016/j.catena.2014.01.016

Wrońska-Wałach, D., Płaczkowska, E., Krzemień, K. (2013). Leje źródłowe jako systemy morfodynamiczne w obszarach górskich. Przeglad Geograficzny, 85(1), 31-51. https://doi.org/10.7163/przg.2013.1.3

Wyżga, B., Kaczka, R.J., Zawiejska, J. (2003). Gruby rumosz drzewny w ciekach górskich-formy występowania, warunki depozycji i znaczenie środowiskowe. Folia Geographica. Series: Geographica-Physica 33-34, 117-138.

Wyżga, B., Kaczka, R., Zawiejska, J. (2012). Zróżnicowanie depozycji grubego rumoszu drzewnego w ciekach górskich o średniej i dużej szerokości. Prace i Studia Geograficzne, 50, 159-169.

Wyżga, B., Zawiejska, J., Mikuś, P., Kaczka, R.J. (2015). Contrasting patterns of wood storage in mountain watercourses narrower and wider than the height of riparian trees. Geomorphology, 228, 275-285. https://doi.org/10.1016/j.geomorph.2014.09.014

Zuchiewicz, W. (1992). Pozycja stratygraficzna tarasów Dunajca w Karpatach Zachodnich. Przeglad geologiczny, 40(7), 436.

Zuchiewicz, W. (1998). Quaternary tectonics of the Outer West Carpathians, Poland. Tectonophysics, 279(1-4), 121-132. https://doi.org/10.1016/S0040-1951(98)00226-1

Zuchiewicz, W. (2001). Geodynamika i neotektonika polskich Karpat zewnętrznych. Przeglad Geologiczny 49, 710-716.

Zuchiewicz, W. (2010). Neotektonika Karpat Polskich i zapadliska przedkarpackiego. Kraków: Wydawnictwo AGH.

Zydroń, T., Bucała, A., Demczuk, P. (2016). Analysis of rainfall-induced shallow landslides in Jamne and Jaszcze stream valleys (Polish Carpathians) - preliminary results. Annals of Warsaw University of Life Sciences-SGGW. Land Reclamation, 48(1), 27-40.

Zydroń, T.A., Gruchot, A.T., Demczuk, P., Bucała-Hrabia, A. (2018). Research of geotechnical properties of slope covers from Jamne and Jaszcze stream valleys in Gorce Mts. Ecological Engineering \& Environmental Technology, 19(1), 44-52. https://doi.org/10.12912/23920629/81646

Żytko, K., Gucik, S., Ryłko, W., Oszczypko, N., Zając, R., Garlicka, L., ... Matějowska, O. (1989). Geological Atlas of Outer Carpathians and their foreland. Warszawa: Państwowy Instytut Geologiczny. 